\title{
A conversation with James Allison
}

had the opportunity to speak with James Allison of the MD Anderson Cancer Center (Figure 1) while he was in New York to collect the 2015 Lasker DeBakey Clinical Medical Research Award in honor of his discovery and subsequent development of monoclonal antibody therapy to unleash the immune system to treat cancer. His work on the T cell antigen receptor, CD28, and CTLA-4 has formed the foundation of immunological research and is the next great hope in cancer treatment. See the full interview on the JCI website (http://jci.org/videos/cgms) for more of his stories on being a musicianscientist and how being called a tumor immunologist used to be an insult.

JCI: Where did you grow up?

Allison: Alice, Texas, a small town in the Rio Grande Valley. Everything outside had needles or would bite you or stick you; it was a pretty harsh environment, a pretty bleak place to grow up. But I had some good teachers who pointed me towards better things: science and medicine. My dad was a country physician. He did house calls and was often paid in tamales. My mother died when I was very young of lymphoma, and so I grew up mostly with my dad and in some foster homes.

JCI: Did he ever impress upon you that he would love to see you follow his footsteps into medicine?

Allison: He would take me on house calls a lot, and he never really forced me to think about going into medicine. I understood that he wanted me to. I was lucky enough to have some laboratory experiences due to some high school teachers that got me involved in summer programs at the University of Texas, Austin. I just loved it. It was just figuring out how much iron yeast needed to grow optimally. I started college as a premed major, but I would watch my dad with patients, and I realized that doctors have to be correct all the time. They have to diagnose what's going on, pull out an algorithm they've memorized, and apply it to the patients. In science, you don't have to be right. You have a hypothesis, and you test it, and you only have to be right some of the time. I thought that being wrong a lot was more fun.

In college, I studied biochemistry, which was a good way to start because it teaches you precision, quantitation, and

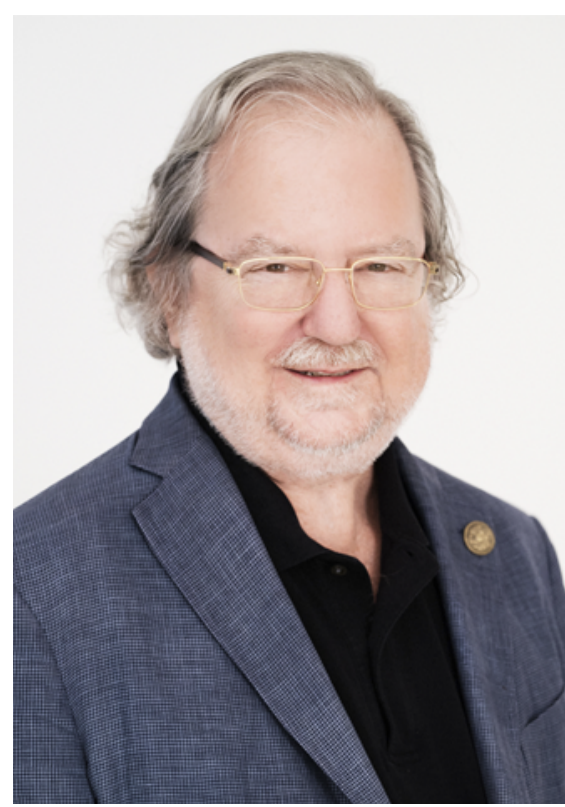

Figure 1. James Allison on September 17, 2015. Image credit: Alexey Levchenko.

the fundamentals. But I got fascinated by the immune system, where there wasn't much precision. The professor that taught me immunology in undergrad wasn't even sure that there was such a thing as $\mathrm{T}$ cells, much less whether they had a specific receptor that could recognize things.

JCI: When in this trajectory did you abandon medical school?

Allison: During my freshman year when I was taking organic chemistry. The way it was taught was just to memorize and regurgitate. I think they intended it to be a culling course, that if you couldn't take it, then you shouldn't be a doctor.

JCI: That was the only class I ever got a $\mathrm{C}$ in as well, so I feel you.

Allison: Yeah, well, I did worse.
JCI: So at this point, you decided to do a PhD.

Allison: At the time, I was working on asparaginase. I felt that I had to do medically related research in order to avoid going to Vietnam because I was at the age of being drafted. Asparaginase was being used at the time to treat children with leukemia because a lot of leukemias lack the ability to make it. My PhD thesis was about trying to come up with a better enzyme to inject into people. One of the things I did just because it seemed interesting - I tried curing mice of lymphoma with this enzyme treatment. I also decided to reinject them with the same tumor and they were immune, and I was reading about tumor transplantation antigens. I treated mice with this drug that deprives them of an essential nutrient, and yet they're immune. That was in the back of my head for a long time.

I really wanted to go from being a biochemist into becoming an immunologist, so for my postdoc, I got into the Ralph Reisfeld laboratory at Scripps Clinic. But my project was purifying MHC molecules for amino acid sequencing to try to figure out the structure; it was a little frustrating because I got to see immunology going on all around me, but I was doing biochemistry.

With another postdoc I did some side experiments on how tumors are recognized by the immune system. When we showed Reisfeld a paper we wrote, he actually said, "I don't want my name on it. You guys just did it." We submitted to Nature, and it was published; we got a lot of notoriety for that.

JCI: Then you went back to Texas?

Allison: I heard that they were opening a research lab that MD Anderson was operating near Smithville, Texas, about a 40-minute drive from Austin. My experience there was quite good. Mostly I think because at the main campus, they forgot about us, so I was free to do whatever I wanted. The initial project was to make monoclonal antibodies and that was fine, but I still wanted to do more fundamental immunology. At the time, the raging, burning question in immunology was, what do $\mathrm{T}$ cells use to recognize antigen? 
One day I went to the main campus to hear Irv Weissman give a talk, and I had one of these "aha moments" during his seminar. I had an idea of how to identify the $\mathrm{T}$ cell antigen receptor and went back to Smithville and sort of dropped everything else and launched into it. I worked out the structure of the $\mathrm{T}$ cell antigen receptor and then went to Irv's lab for a sabbatical year.

JCI: After that, you were recruited to Berkeley?

Allison: While I was in Irv's lab, the late Bunny Koshland asked me to come to Berkeley to give a seminar, and I did, and a couple of weeks later, they offered me a job. I was an assistant professor in Smithville, and they offered me a full professorship at Berkeley. It was intimidating, the big science, the whole thing. And I was happy in Texas; we were really collegial, where everybody helped everybody else work, and I took a long time to make a decision. Finally, Irv called me and said, "What do you want to do, Jim? In 20 years, you're going to sit on your porch, say 'I could've been a contender!'?" So I accepted the job at Berkeley.

JCI: It's during this time that you then started to develop your ideas about CD28 and activation/deactivation signals of the immune system?

Allison: We had worked out the structure of the antigen receptor, and I took a purely structural biochemical approach, and others had taken more of a functional approach. Some really incredible work by Ron Schwartz and Marc Jenkins showed there were costimulatory signals that were required for activation. I became interested in what those were, and based on others' work with the molecule CD28 that sounded like the right actor to be the costimulatory signal. But the key thing about costimulation was there's a second signal that you have to engage in addition to the antigen receptor to get a naive $\mathrm{T}$ cell to go. That was what I really wanted to find. We and others cloned the gene for CD28 and probed and cloned the mouse version and expressed it on the cells, developed monoclonal antibodies to it, and showed that engagement of CD28 was sufficient and necessary as a second signal.

When we cloned CD28, we put the sequence in the gene bank and asked what was related, and there was this molecule called CTLA-4 that Pierre Golstein had identified, and all he knew about it was that it's in all T cells after activation, but that was the key: it's not in resting T cells - it's only expressed after activation. The extracellular domain of CTLA-4 clearly had to have something to do with CD28.

The first person to really get into it was Peter Linsley, and he made a recombinant form of the molecule and showed that CD28 binds to these molecules called B7 that are restricted to dendritic cells. Then he made an antibody to it and threw it in a culture with $\mathrm{T}$ cells being activated with antibodies to the $\mathrm{T}$ cell receptor and threw in antibodies to CTLA-4 and showed that it increased proliferation, so he concluded that it was another activating costimulatory molecule. We did the same experiments, but you had to add it in soluble form rather than crosslinking form. We got the same results, but the fact that it was in soluble form worried me because most antibodies block; they don't activate. Jeff Bluestone had the same idea independently.

JCI: So you had the heretical idea that CTLA- 4 was an inhibitor?

Allison: Yep. And it was close to three years until Tak Mak and Arlene Sharpe and the late Cynthia Chambers from my lab made knockout mice, and they basically turned into a big lymph node because their T cells couldn't stop dividing. It was realized that CTLA-4 is an essential downregulator.

I had some students who had grown tumors in mice and injected them with CTLA-4 antibody. I expected the antibody to slow tumor growth, but the mice that got that CTLA-4 - they were cured. I couldn't believe the results. I asked them to set up the experiment again in a blinded fashion. I kept measuring the tumors, and it was kind of depressing because they all grew; for the first several measurements, there was no difference between the groups, but then at some point - I think it was two days after Christmas - one group had sort of flattened out, wasn't growing anymore. As I followed it, some of them just went away. At that point, I said, "Oh, this is big."

JCI: Bristol-Myers Squibb held a patent declaring that CTLA-4 was an immune stimulant, so they were not about to make a humanized antibody to put into people. How arduous was the process to get a company to develop a humanized antibody?

Allison: I spent almost two years going around and talking to big pharma and some small biotech firms, and there was a lot of skepticism, but the data were the data. By that time, we had done it against many different types of tumors and in many strains of mice to show that it was generalizable. I'd gone to Rick Klausner, who was the head of the NCI at the time, and said, "I can get grants, and I can study this, but we need to be able to treat cancer in people. So NCI ought to get involved. I mean, are you interested in just funding clever grants or in curing cancer?"

Several iterations were needed to get to the antibody, but eventually a guy named Nils Lonberg, who had a company that was originally called GenPharm, then was bought by Medarex - they had mice that had human immunoglobulin genes instead of mouse and therefore made fully human antibodies. They agreed to take on CTLA-4 and made an antibody, MDX-010, which became ipilimumab.

JCI: At this time Harold Varmus from Sloan Kettering came a-calling?

Allison: By then I was totally committed to seeing this go into humans, and so I started looking around. Sloan Kettering kind of resonated. Medarex and BristolMyers Squibb and all the drug companies were in the New York area; I decided to go there and learn about the clinic and make sure that nobody hurt my baby.

JCI: You watched your baby grow all the way to FDA approval.

Allison: It was really cool, but at the time it was still abstract. I've had a lot of cancer in my family, but that wasn't really why I was doing the work. I was doing the work because I wanted to understand $\mathrm{T}$ cells, but when I realized what we could do with this, then I became really committed to making sure nobody screwed it up.

JCI: What else do you think could have kept you engaged over these years?

Allison: When I was a postdoc, I played with a band a couple of times a week. It took its toll, staying up late and drinking too much beer, but it was fun. It's a wonderful sort of thing when you really have a band really clicking. I don't think I would have done well - I'm not that good, but I did have a point when I was postdoc when the band I played with decided to move back to Central Texas and play the Gruene Hall dance circuit and I said, "No, I can't go, I've got a day job. I've got to stick with that."

\section{Ushma S. Neill}

